\title{
Measuring Accounting Professionals Perception on use of AI Based Accounting Practices in India
}

\author{
Vineet Chouhan, Pushpkant Shakdwipee, M. L. Vasita, Punam Chand
}

\begin{abstract}
Accounting as a progressive domain of knowledge is now ready to adapt new changes and understand how to effectively respond. Artificial intelligence (AI) has brought new challenges and solutions of old problems. It is intense technology not for replacing people but for improving importance of purely human skills like enthusiasm, creativity or empathy: all essential aspects of profession. AI is used for enhancing the human experience for decision making. This means deleting the monotonous work out from employee's schedule and converting their skills towards managerial decision making. It deals with Large volumes of information that previously used to be succeeded by workforces are now controlled by AI while they can contentedly examine it. Composite altering patterns can be accustomed very easily in the data. These arrangements are extremely dependable than the previously tracked techniques. This research paper analyses measures the use of $A I$ in accounting, auditing and recruiting with measuring its benefits and challenges. For this purpose a sample of 104 accounting professionals were taken and analysed by using regression method with SPSS software and revealed the hidden potentials of $A I$ in the area of accounting profession.
\end{abstract}

Keywords: Accounting Professionals, Artificial intelligence, India, Perception.

\section{INTRODUCTION}

New technology emergence has heartened accountants to combine human skills with unreachable by machines like storytelling, effective communication and relationship building (Suchan \& Hayzak, 2001). Artificial intelligence (AI) is amongst one of the new technology that can be adopted by various industries in recent past. AI is a comprehensive term that denotes to knowhow that convert the machines smart (Zhong, et.al, 2017). Establishments are advancing in AI investigation and solicitations to systematize, enhance, or reproduce human intelligence, analytical and/or decision-making (Michailidis, 2018;

Revised Manuscript Received on February 05, 2020.

* Correspondence Author

Dr. Vineet Chouhan *, Assistant Professor, School of Management, Sir Padampat Singhania University, Udaipur, Rajasthan, India, Email: vineet.chouhan@spsu.ac.in \& vcpc2008@gmail.com.

Dr. Pushpkant Shakdwipee, Associate Professor, PIM, Pacific University, Udaipur- Rajasthan. Email: pushpkant1978@gmail.com

Dr. M. L. Vasita, Associate Professor, University of Rajasthan, Jaipur. drmlvasita@gmail.com.

Dr. Punam Chand, Assistant Professor, Head, Department of Commerce, SMCC Government College, Abu Road, Rajasthan, India. punitchawla2111@gmail.com.

(C) The Authors. Published by Blue Eyes Intelligence Engineering and Sciences Publication (BEIESP). This is an open access article under the CC BY-NC-ND license (http://creativecommons.org/licenses/by-nc-nd/4.0/)
Nweze, 2019). The accounting profession must be prepared to fully participate in organizational AI initiatives (Thousand, et.al.,2006; DiMaggio \& Powell, 1983). It has an algorithm that is a customary of instructions for the device to track. An algorithm is there to make them empowers for rapid progression of massive quantities of data that a person cannot realistically progress or even understand. The presentation and exactitude of algorithms is identically significant (Wu et.al., 2008).

The application of AI has great potential in the area of accounting. It has the prospective to assist accountants for its relevance and value, with the correct boldness and achieve the skills essential (Creed, et.al., 1996). Many organizations have begun used it for modernizing developments and gaining improvement over the rivals. It is usually being used to procedure immense dimensions of data at prompt speeds, like how worksheet programs work now. Further, cunnings that require additional detail and investigation will still be completed by humans. Larger firms used it in auditing procedures and approximations (Sharma,et.al., 2012). It can be used for reducing time to identify nonconformity matters in economic data. It can routinely notice operative expense damages such as forbidden or individual spend, unverifiable receipts, personal credit card usage, disallowed merchants and travel add-ons (Rasch, et. al., 2002).

Now companies can also control which strategies are employed for the company, as well as whether convinced rule destructions are admissible. It collect and review values to helps finance-managers identify tendencies to make data-driven recommendations for their client's commercial policies (Rygielski et.al., 2002; Sagiroglu \& Sinanc, 2013; Gottesdiener, 1997)

Intellectual machines concept were found in Greek mythology too. Arab inventor built something in 1206 believed to be the initial programmable anthropological robot. Pascal has generated the first calculator (1642). Till 1912 first "computer" game founded as game of chess originated along in the early 20th century. In 1936 Alan Turing first recommended the impression of the Touring Machine that was the basis for theories about computers and computing (AI Topics, 2016). Use of AI made possible for GM to double its production of 110 car per hour in 1969 , it reached up to highest rate of any other automotive capability in presence (Griffin, 2016). The term "AI" was first brought up at the Dart mouth seminar at 1956. Since then, researchers have developed many theories and principles, and the concept of AI has also been expanded. AI, in essence, is a simulation of the process of thinking and information obtaining (Xing et.al, 2017). are fine and satisfactory.

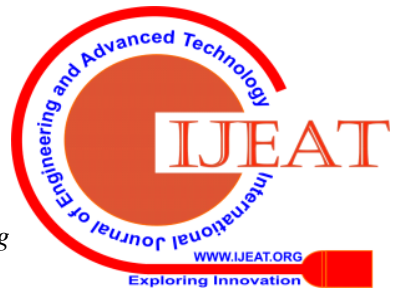




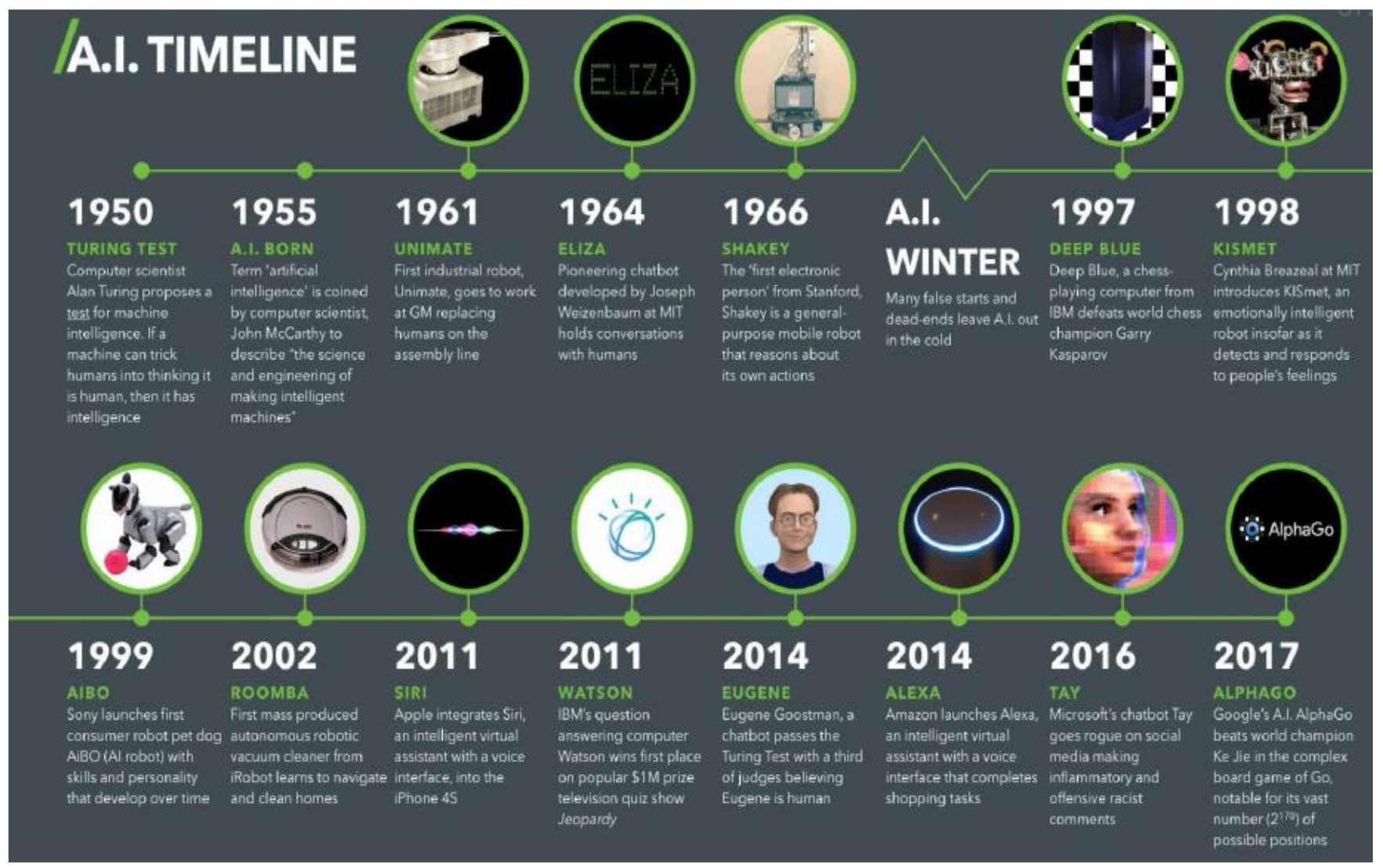

\section{REVIEWS OF LITERATURE}

Greenman (2017) revealed AI that AI is not hazardous to the forthcoming generations of auditing and accounting vocations. The operation of AI in this area has root date back to eras ago. Odoh et.al., (2018) studied 185 certified public accountant and managers in accounting companies in Enugu state and Anambra; found that AI application has definite inspirations the presentation of accounting occupations. The investigators suggested that bookkeepers and accounting firms must frequently advance their knowledge regarding AI as this will improve the presentation of accounting meanings, thereby removing assure cost in the area of accounting. According to Dilek et.al.,(2015). AI emerged as a research discipline at the Summer Research Project of Dartmouth College in July 1956. It is developed in today's world as noticeable as today's business setting and process holds digital expertise complete the implementation of machine equipment. As per Carol \& O'Leary (2013) the area of accounting has a past of AI submissions successfully back over the years. Therefore, all structures of accounting, mainly afraid with evidence have been prejudiced by AI expertise as definite types can be functional in case of a few information happenings in the area of accounting. Yang \& Vasarhelyi (1997) clarify the present submission of skilled systems in bookkeeping. The parts of stress covered are: Auditing, Taxation, Financial Accounting, Personal Financial Planning, and Management Accounting. The focus is mainly on US research and applications. Back et. al. (1997) ensured considering using AI paradigm. Later the Cheh et.al., examined the efficacy of the neural technology as an investment expert system and proposes a framework for evaluation.. Baldwin-Morgan (1997) attempted a comprehensive discussion of the applicability of expert systems to auditing and the impacts of expert systems on audit firms. Herbert et al. (2016) explored the possibilities for transforming the way professional work in the future, by using automation. The study describes that since automation is used to eliminate routine and repetitive tasks, it will allow employees to focus on more creative, non-structured tasks that require more thinking. While focusing more on creative, non-structured tasks, the value of the accountant's contributions will increase. Beaman (et al., 2007) studied the role of the management accountants in the future and state that the accountant's role is dominated by scorekeeping and other requirements. Accountants need to develop their skills regarding the use of AI if the employees want to keep adding value to the firm. Al-Htaybat et al.,(2017) revealed that accounting companies are looking for employees who are not afraid of technology, but who are creative and open-minded. These employees also need to know how to work with and how to use the data provided by technology.

Study conducted by the Boston Consulting Group revealed the importance of AI and its use as they have taken survey of 3,000 executives, managers and forecasters, $83 \%$ of defendants measured AI as significant for their occupation and approach, although 63\% feel their company must use it soon within 5 years to decrease cost (Sarah Ovaska-Few, 2017). Indeed, a current worldwide research of 3,000 accountants, approved by Sage-publisher, establishes that $83 \%$ were being requested by their customers to spread their amenities.

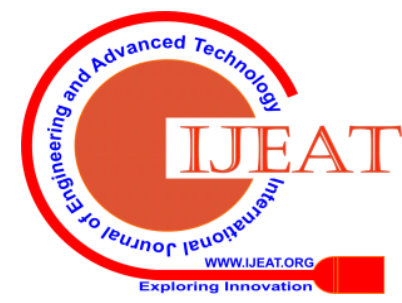


For example, 42\% predictable bookkeepers to deliver consultancy and information. As a result, certified public accountant are irritating to be allowed time by functioning other responsibilities further professionally. Indeed, the new global revision by Sage shown that $50 \%$ of the 3,000 accountants were observing to $\mathrm{AI}$ and computerization knowledge to free up their time to meet advance client demands (Sage report, 2019).

\section{RESEARCH METHODOLOGY}

The methodology followed for the study is presented as under:

\section{A. RESEARCH TYPE}

Research type of the study includes exploratory research design for which a questionnaire is design by taking variables from the reviews of literature.

\section{B. SCOPE OF RESEARCH}

The scope of the study is limited up to the 62 companies of Rajasthan and their accounts managers and professional working in those companies.

\section{SAMPLE SIZE}

The size of sample is 62 companies and 104 respondents selected from those companies using AI in their daily working. The companies selected from the RICCO industrial area of Udaipur and Jaipur included in the study.

D. DATA TYPE

Both primary and secondary data were gathered for the purpose of current study;

Primary data has been obtained through a questionnaire from 104 Auditors, Accountants and Managers of selected companies. Those who has filled the dependent variable data in appropriate form is finally selected for the study.

Secondary data: the secondary data were gathered from research paper, financial report, ISAB review previous studies, internet, and online libraries including EBSCO.

\section{DATA ANALYSIS}

The data gathered from the respondents are presented for their demographical profile in table-1 as under:

\begin{tabular}{|c|c|c|c|c|c|}
\hline \multicolumn{6}{|c|}{ Table-1: Demographic Profile } \\
\hline \multirow[t]{4}{*}{ Age } & Below 25 & $8 \%$ & \multirow[t]{2}{*}{$\begin{array}{l}\text { Sector of } \\
\text { company }\end{array}$} & $\begin{array}{l}\text { Manufac } \\
\text { turing }\end{array}$ & $78 \%$ \\
\hline & $25-35$ & $25 \%$ & & Service & $22 \%$ \\
\hline & $35-45$ & $56 \%$ & \multirow{5}{*}{$\begin{array}{l}\text { Primary } \\
\text { function } \\
\text { of the } \\
\text { company }\end{array}$} & $\begin{array}{l}\text { Investor } \\
\text { Relation }\end{array}$ & $4 \%$ \\
\hline & $\begin{array}{l}45 \& \\
\text { above }\end{array}$ & $11 \%$ & & IT & $25 \%$ \\
\hline \multirow{7}{*}{\begin{tabular}{|} 
Educat \\
ion
\end{tabular}} & Post & & & Finance & \\
\hline & Graduate & $21 \%$ & & & $61 \%$ \\
\hline & CA & $28 \%$ & & Treasury & $10 \%$ \\
\hline & $\mathrm{CS}$ & $17 \%$ & \multirow{3}{*}{$\begin{array}{l}\text { Your } \\
\text { Experienc } \\
\text { e }\end{array}$} & $<5$ years & $15 \%$ \\
\hline & ICWAI & $18 \%$ & & 5 to 15 yrs. & $54 \%$ \\
\hline & \multirow[t]{2}{*}{ CPA } & & & $>5$ years & $31 \%$ \\
\hline & & $16 \%$ & \multirow{3}{*}{$\begin{array}{l}\text { Occupatio } \\
\mathrm{n}\end{array}$} & Auditor & $29 \%$ \\
\hline \multirow{2}{*}{$\begin{array}{r}\text { Gende } \\
\mathrm{r}\end{array}$} & Male & 74.0 & & Accountant & $43 \%$ \\
\hline & Female & 26.0 & & Manager & $28 \%$ \\
\hline
\end{tabular}

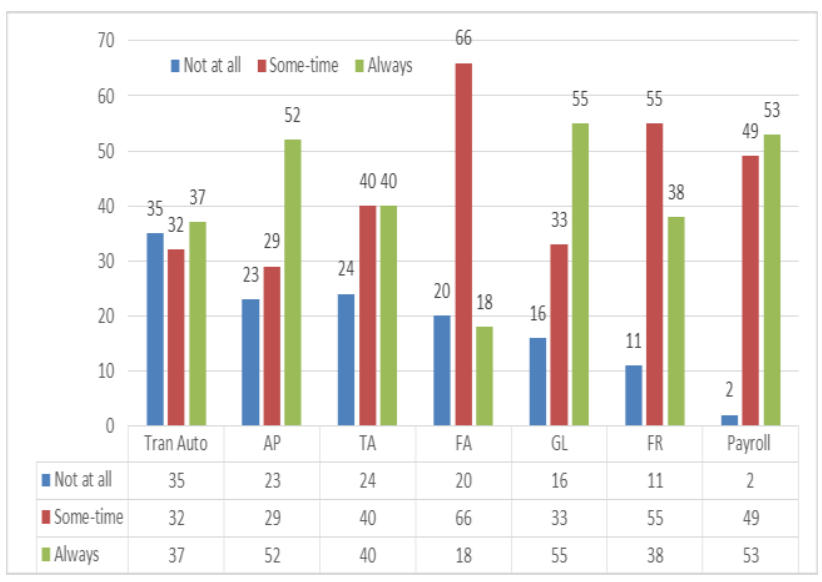

Figure-1: Using AI for which transaction

First the distributions of responses in respect of the using AI for various types of transaction were measured. The above figure revealed that the AI is used mostly by the companies for General ledger followed by payroll and accounts payable.it is used sometimes for complete Financial Accounting, fixed assets management and payroll related information.

Further since the organisations are using AI, thus it is important to measure that whether which method is used by the companies frequently for using $\mathrm{AI}$ in the organisations, the following hypothesis were made:

$\mathrm{H}_{1(\mathrm{a})}=$ Significant changes exists in the method of AI by the companies.

To test the above hypothesis the test were being used with average change of 2 and above; to identify the gap between methods of adoption of AI with SPSS-19 software. The consequences were delivered in table-2 as under:

Table-2: $t$ test

\begin{tabular}{|l|l|l|l|l|}
\hline & $\mathrm{N}$ & $\mathrm{X}$ & $\sigma$ & $\sigma$ Error \\
\hline USE_AI_1 & 104 & 2.0192 & .83586 & .08196 \\
\hline USE_AI_2 & 104 & 2.2788 & .80601 & .07904 \\
\hline USE_AI_3 & 104 & 2.1538 & .77296 & .07579 \\
\hline USE_AI_4 & 104 & 1.9808 & .60709 & .05953 \\
\hline USE_AI_5 & 104 & 2.3750 & .73982 & .07255 \\
\hline USE_AI_6 & 104 & 2.2596 & .63849 & .06261 \\
\hline USE_AI_7 & 104 & 2.4904 & .53960 & .05291 \\
\hline
\end{tabular}

\begin{tabular}{|c|c|c|c|c|c|c|}
\hline \multicolumn{7}{|c|}{ t Test } \\
\hline & \multirow[b]{2}{*}{$t$} & \multirow[b]{2}{*}{$\mathrm{df}$} & \multirow{2}{*}{$\begin{array}{l}\text { Sig. } \\
\text { (2-taile } \\
\text { d) }\end{array}$} & \multirow[b]{2}{*}{\begin{tabular}{|l} 
Mean- \\
Diff.
\end{tabular}} & \multicolumn{2}{|c|}{$\begin{array}{l}\text { 95\% Con. } \\
\text { Interval } \\
\text { (Difference) }\end{array}$} \\
\hline & & & & & Lower & $\begin{array}{l}\text { Uppe } \\
\mathrm{r}\end{array}$ \\
\hline USE_AI_1 & .235 & 103 & .810 & .01923 & -.1433 & $\begin{array}{l}.181 \\
8\end{array}$ \\
\hline USE_AI_2 & 3.528 & 103 & .010 & .27885 & .1221 & $\begin{array}{l}.435 \\
6\end{array}$ \\
\hline USE_AI_3 & 2.030 & 103 & .045 & .15385 & .0035 & $\begin{array}{l}.304 \\
2 \\
\end{array}$ \\
\hline USE_AI_4 & -.323 & 103 & .747 & $\begin{array}{l}-.0192 \\
3\end{array}$ & -.1373 & $\begin{array}{l}.098 \\
8\end{array}$ \\
\hline USE_AI_5 & 5.169 & 103 & .000 & .37500 & .2311 & $\begin{array}{l}.518 \\
9 \\
\end{array}$ \\
\hline
\end{tabular}




\begin{tabular}{|l|l|l|l|l|l|l|}
\hline USE_AI_6 & 4.147 & 103 & .000 & .25962 & .1354 & $\begin{array}{l}.383 \\
8\end{array}$ \\
\hline USE_AI_7 & 9.268 & 103 & .000 & .49038 & .3854 & $\begin{array}{l}.595 \\
3\end{array}$ \\
\hline
\end{tabular}

The output of the ' $t$ test' is presented in table-2, shows noteworthy gap happens amongst the conjectured test worth with the intended sample figures for vicissitudes were made due to adoption of the AI by the companies $(\mathrm{p}<0.05)$ at $5 \%$ level of significance. The respondents have exhibited a fair amount of agreement for Accounts Payables, Travel expenses, General Ledger, Financial Reporting and Payroll and workforce management were used by the organizations frequently.
Further since the organizations are using AI, thus it is important to measure that whether there is any Policy change has happened due to the application of $\mathrm{AI}$ in the organizations, the following hypothesis were made:

$\mathrm{H}_{1(\mathrm{a})}=$ The attributes configuring use of AI in various companies has made significantly policy changes, got significant benefits and found significant challenges with adoption of the AI by the companies.

To recognize main variables in policy changes, benefits and challenges multivariate (multiple regression investigation has been incorporated with SPSS-19 software and consequences were exposed in table 3 as under:

Table-3: Multiple regression analysis Result $(\mathrm{N}=104)$

\begin{tabular}{|c|c|c|c|c|c|}
\hline Var. & Var. name & Adj. $R^{2}$ & $\beta$ & ANOVA. & Sig. \\
\hline \multirow[t]{2}{*}{ Policy changes } & Pol_chang_6 & \multirow[t]{2}{*}{0.335} & .488 & \multirow[t]{2}{*}{26.905} & \multirow[t]{2}{*}{$0.000^{\mathrm{b}}$} \\
\hline & Pol_chang_3 & & 287 & & \\
\hline \multirow[t]{3}{*}{ Benefit } & Benefits_3 & \multirow[t]{3}{*}{0.143} & .286 & \multirow[t]{3}{*}{6.715} & \multirow[t]{3}{*}{0.000} \\
\hline & Benefits_12 & & .190 & & \\
\hline & Benefits_18 & & -.214 & & \\
\hline \multirow[t]{4}{*}{ Challenges } & Challang_4 & \multirow[t]{4}{*}{0.160} & .285 & \multirow[t]{4}{*}{5.919} & \multirow[t]{4}{*}{$.000^{\mathrm{d}}$} \\
\hline & Challang_3 & & .305 & & \\
\hline & Challang_9 & & .224 & & \\
\hline & Challang_2 & & -.225 & & \\
\hline
\end{tabular}

Further the ANOVA examination delivers the arithmetical

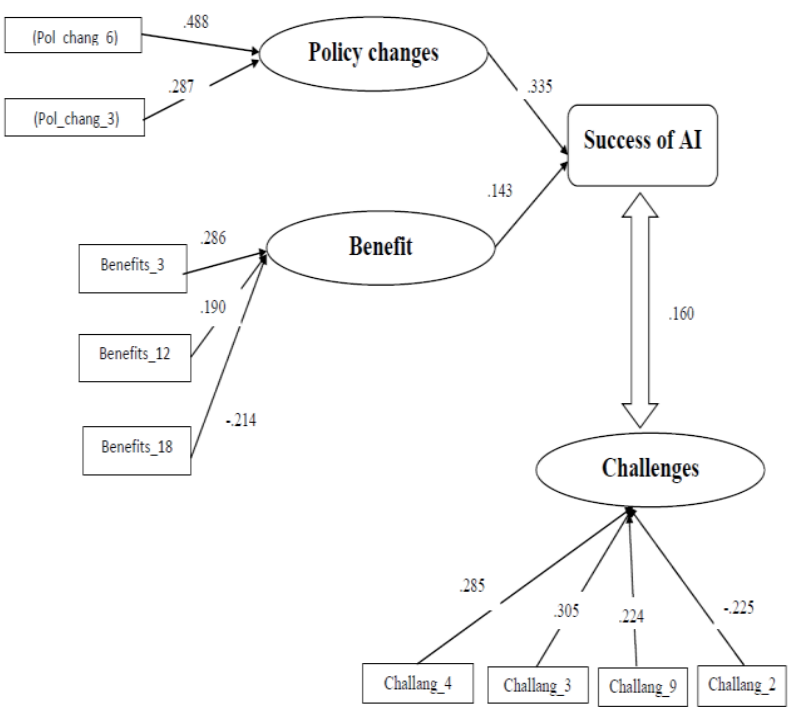

Figure-2: AI model

\section{CONCLUSION}

The final Regression model with 2 independent variables (Pol_chang_6, Pol_chang_3) explains almost 33.5\% of the variance of Policy change pertaining to companies practice/working. For Benefits of AI final Regression model with 3 independent variables (Benefits_3, Benefits_12 and Benefits_18) explains almost $14.3 \%$ of the variance of Policy change pertaining to companies practice/working. For challenges of AI final Regression model with 4 independent variables (Challang_4, Challang_3, Challang_9 and Challang_2) explains almost $16 \%$ of the variance of Policy change pertaining to companies practice/working. examination for overall model fitting in terms of F-Ratio. The total sum of squares(SS) is the adjusted inaccuracy that would accumulate if the mean of corporations rehearsal/working remained to forecast the dependent variables(DV). Using the standards of designated variables this blunders can be condensed significantly. This reduction is deemed statistically significant with the F ratio of 26.905; 6.715 and 5.919 and significance at level of 0.000 .

With the above analysis it can be conclude that 2 independent variables Mitigating repetitive tasks (Pol_chang_6) and Enhancing powers of observation and detection (Pol_chang_3) explains the policy changes as per adoption of AI.

Independent variables acquittal up interval to emphasis on additional valuable responsibilities includes as decision-making, unruly resolving, counseling, strategy expansion, association building and management (Benefits_3), Smart User Interfaces (Benefits_12) and it studies as it progresses, the yields from AI can be tremendously precise and can make an increase on human efforts reducing error (Benefits_18) explains benefits. For challenges of AI final Regression model with 4 independent variables The Quality of Professional Talents Needs to Be Improved (Challang_4), High Investment with Slow Return (Challang_3), Innovativeness Organization Attaches Countless Standing to the Application of AI-Technology (Challang_9) and Lack of Experience in the Initial Stage (Challang_2) explains the challenges pertaining to use of AI by selected companies. 


\section{REFERENCES}

1. AI-Topics.(2016). Brief History of Artificial Intelligence. http://aitopics.org/topic/brief-histories-timelines.

2. Al-Htaybat,K. \& Alberti-Alhtaybat,L.-von (2017). Big Data and corporate reporting: impacts and paradoxes. Accounting, Auditing and Accountability Journal. 2017;30;4: 850 - 873.

3. Back et.al.,(1997).Artificial Intelligence in Accounting and Auditing: Towards New Paradigms, Volume , eds. Vasarhelyi, Miklos A. and Kogan, Alex Markus Wiener Publisher: NJ- USA

4. Baldwin,A.A., Brown,C.E. \& Trinkle,B.S. (2006). Opportunities for artificial intelligence development in the accounting domain: the case for auditing. Wiley Periodicals Inc. 2006;14;3:77 - 86

5. Baldwin-Morgan(1997).Artificial Intelligence in Accounting and Auditing: Towards New Paradigms, Volume , eds. Vasarhelyi, Miklos A. and Kogan, Alex Markus Wiener Publisher: NJ- USA

6. Beaman,I. \& Richardson,B.(2007). Information Technology, Decision Support and Management Accounting Roles. Journal of Applied Management Accounting Research. 2007;5;1: 59 - 68.

7. Carol EB, O'Leary D. (2013). Introduction to artificial intelligence and export system;.(Retrieved on 6/10/2017) Available: http://www.mbsfile03.uscredu/dia Ltalmeasures

8. $\quad$ Creed,W.D., Miles,R.E., Kramer, R-M., \& Tyler, T-R.(1996). Trust in organizations. Trust in organizations: Frontiers of theory and research, 16-38.

9. Dilek,S., Çak?,H., Ayd?n andM. (2015). Applications of artificial intelligence techniques to combating cyber-crimes: A review. International Journal of Artificial Intelligence \& Applications (IJAIA); 6(1).

10. DiMaggio, P.J., \& Powell, W.W.(1983). The iron cage revisited: Institutional isomorphism and collective rationality in organizational fields. American sociological review, 147-160.

11. Gottesdiener, E.(1997). Business rules show power, promise. Application Development Trends, 4(3), 36-42.

12. Graetz,G and Michaels,G.(2015). Estimating the impact of robots on productivity and employment. Center for Economic Performance. http://cep.lse.ac.uk/pubs/download/dp1335.pdf.

13. Greenman, C.(2017). Exploring the impact of artificial intelligence on the accounting profession. Journal of Research in Business, Economics and Management (JRBEM);:8(3):1451-1454.

14. Griffin, O. (2016). How artificial intelligence will impact accounting. Economia.

15. Herbert, I., Dhayalan, A. \& Scott, A. (2016). The future of professional work: will you be replaced, or will you be sitting next to a robot? Management Services. 2016;60;2: 22 - 24, 26 - 27,

16. Michailidis, M. P. (2018). Hie Challenges of AI and Blockchain on HR Recruiting Practices. Cyprus Review, 30(2).

17. Nweze, A. U. (2019). opportunities and threats posed by artificial intelligence on the accounting profession: emphasis on the sub-sahara african region. in th 5 annual international academic conference proceedings, 2019 (p. 1).

18. Odoh, Longinus Chukwudi, Silas C. Echefu, Ugwuanyi, Uche Boniface and Chukwuani, Nnenna Victoria.(2018), Effect of Artificial Intelligence on the Performance of Accounting Operations among Accounting Firms in South East Nigeria Asian Journal of Economics, Business and Accounting, 7(2): 1-11,;

19. Ransbotham, S., Kiron,D, Gerbert, P., And Reeves,M.(2017). Reshaping business with artificial intelligence Closing the Gap Between Ambition and Action, https://sloanreview.mit.edu/projects/reshaping-business-with-artificial -intelligence/

20. Rasch, R., Kott, A., \& Forbus, K. D. (2002). AI on the battlefield: An experimental exploration. In AAAI/IAAI (pp. 906-912).

21. Rygielski, C., Wang, J. C., \& Yen, D. C. (2002). Data mining techniques for customer relationship management. Technology in society, 24(4), 483-502.

22. Sage report (2019) Practice of Now 2019 report, https://www.sage.com/en-gb/cp/practice-of-now/

23. Sagiroglu, S., \& Sinanc, D. (2013). Big data: A review. In 2013 International Conference on Collaboration Technologies and Systems (CTS) (pp. 42-47). IEEE

24. Sangster piece (1997).Artificial Intelligence in Accounting and Auditing: Towards New Paradigms, Volume , eds. Vasarhelyi, Miklos A. and Kogan, Alex Markus Wiener Publisher: NJ- USA
25. Sarah Ovaska-Few(2017). How artificial intelligence is changing accounting, journal of accountancy, https://www.journalofaccountancy.com/newsletters/2017/oct/artificial -intelligence-changing-accounting.html

26. Sharma,B., Frontiera,R.R., Henry,A.I., Ringe,E., \& Van Duyne, R.P.(2012). SERS: Materials, applications, and the future. Materials today, 15(1-2), 16-25.

27. Suchan,J., \& Hayzak,G.(2001). The communication characteristics of virtual teams: A case study. IEEE transactions on Professional Communication, 44(3), 174-186.

28. Thousand, J. S., Villa, R. A., \& Nevin, A. I. (2006). The many faces of collaborative planning and teaching. Theory into practice, 45(3), 239-248.

29. Wu,X., Kumar,V., Quinlan,J. R., Ghosh,J., Yang, Q., Motoda,H. \& Zhou, Z. H.(2008). Top 10 algorithms in data mining. Knowledge and information systems, 14(1), 1-37.

30. Xing Afeng, tao xuemei, peng ruifeng. (2017). Reflections on the accounting industry in the era of artificial intelligence $[\mathrm{J}]$. Accounting and accounting studies, (10):112-112.

31. Yang \& Vasarhelyi (1997).Artificial Intelligence in Accounting and Auditing: Towards New Paradigms, Volume, eds. Vasarhelyi, Miklos A. and Kogan, Alex Markus Wiener Publisher: NJ- USA

32. Zhong,.R.Y., Xu,X., Klotz,E., \& Newman,S.T. (2017).Intelligent manufacturing in the context of industry 4.0.: A reviewEngineering, 3(5), 616-630.

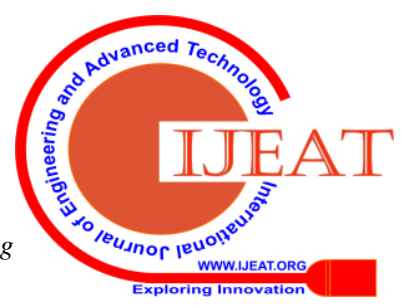




\section{Measuring Accounting Professionals Perception on use of AI Based Accounting Practices in India}

Appendix-1: Questionnaire Demographic Profile

\begin{tabular}{|c|c|c|c|c|c|c|c|c|}
\hline \multicolumn{9}{|c|}{ (nlease Tick any one in each category) } \\
\hline \multirow{4}{*}{ Age } & Below 25 & \multirow{2}{*}{\multicolumn{2}{|c|}{$\begin{array}{l}\text { Sector of } \\
\text { company }\end{array}$}} & \multicolumn{4}{|c|}{ Manufacturing } & \\
\hline & $25-35$ & & & \multicolumn{4}{|c|}{ Service } & \\
\hline & $35-45$ & \multirow{4}{*}{\multicolumn{2}{|c|}{$\begin{array}{l}\text { Primary function } \\
\text { of the company }\end{array}$}} & \multicolumn{4}{|c|}{ Investor Relation } & \\
\hline & $45 \&$ above & & & \multicolumn{4}{|c|}{ IT } & \\
\hline \multirow[t]{6}{*}{ Education } & Post Graduate & & & \multicolumn{4}{|c|}{ Finance } & \\
\hline & CA & & & \multicolumn{4}{|c|}{ Treasury } & \\
\hline & CS & \multirow{3}{*}{\multicolumn{2}{|c|}{ Your Experience }} & \multicolumn{4}{|c|}{ Less than 5 years } & \\
\hline & ICWAI & & & \multicolumn{4}{|c|}{5 to 15 years } & \\
\hline & CPA & & & \multicolumn{4}{|c|}{ Less than 5 years } & \\
\hline & & \multirow{3}{*}{\multicolumn{2}{|c|}{ Occupation }} & \multicolumn{4}{|c|}{ Auditor } & \\
\hline \multirow{2}{*}{ Gender } & Male & & & \multicolumn{4}{|c|}{ Accountant } & \\
\hline & Female & & & \multicolumn{4}{|c|}{ Manager } & \\
\hline \multicolumn{4}{|c|}{ Using AI for which transaction } & & & $\begin{array}{l}\text { Not at } \\
\text { all }\end{array}$ & $\begin{array}{l}\text { Some-ti } \\
\text { me }\end{array}$ & Always \\
\hline \multicolumn{9}{|c|}{ Transactions to be automated } \\
\hline \multicolumn{9}{|c|}{ Accounts Payables } \\
\hline \multicolumn{9}{|l|}{ Travel expenses } \\
\hline \multirow{2}{*}{\multicolumn{9}{|c|}{$\begin{array}{l}\text { Fixed Assets } \\
\text { General Ledger }\end{array}$}} \\
\hline & & & & & & & & \\
\hline \multicolumn{9}{|c|}{ Financial Reporting } \\
\hline Payroll and wor & force management & & & & & & & \\
\hline & Policy change & & 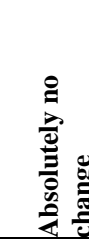 & & 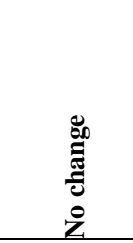 & 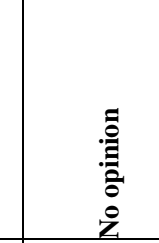 & 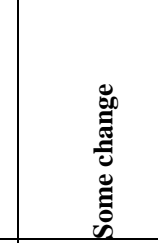 & 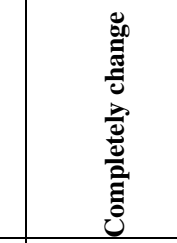 \\
\hline Policy is affecte & in organisations using $\mathrm{A}$ & g purposes & & & & & & \\
\hline Scaling up quan & ity and quality of data ana & & & & & & & \\
\hline Enhancing powt & rs of observation and dete & & & & & & & \\
\hline Augmenting cos & nitive capacity: & & & & & & & \\
\hline Improving cons & stency & & & & & & & \\
\hline Mitigating repet & tive tasks & & & & & & & \\
\hline Reducing errors & & & & & & & & \\
\hline Clearing invoict & s faster & & & & & & & \\
\hline Accelerating da & a analysis & & & & & & & \\
\hline Real-time audits & to ensure compliance & & & & & & & \\
\hline Streamline data & entry and analysis & & & & & & & \\
\hline Reduce fraud & & & & & & & & \\
\hline
\end{tabular}

Major benefits of AI system

Use of AI is subject to the various benefits of the organisations

Making new understandings from the examination of data

Acquit period to emphasize on further valued

Procedures based approaches advance accurateness for empowering greater automation of procedures

Refining fraud detection (sophisticated, machine learning representations) and better forecasting of fraudulent actions

Using machine learning centered extrapolative prototypes to forecast incomes

improving entree and examination of, formless data, through e-mails, deep learning models etc.,

Accounting Information Not Meeting Needs of Decision Makers.

Inability for Humans to Process or Understand What is Captured in the Computerized Accounting Databases.

A Focus on Numeric Data.

Interpretation of the Relationship Between Transactions to Yield Actual Events.

Systems Are Difficult to Use 
Smart Convergence of "Old Files Into New "

Smart Restructuring the Organization of the Database

Smart User Interfaces

Models to Process Database Information

improve the Quality of Accounting Education in Colleges

Accounting Talents Establish the Idea of Life-Long Learning

Accurate outputs after development with reduction in errors

Automated and streamlined accounting errands

In elevation speed of data procession with multifaceted data without any biasness

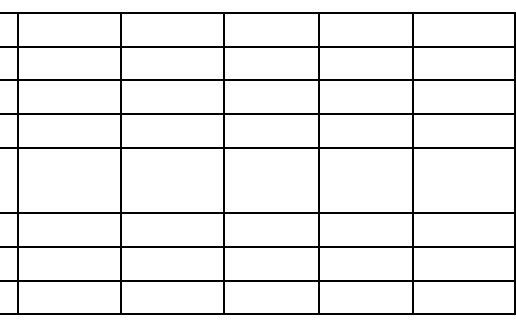

\begin{tabular}{|c|c|c|c|c|c|}
\hline CHALLENGES & $\begin{array}{l}\text { न } \\
\text { है } \\
\text { है } \\
\end{array}$ & 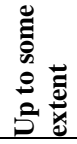 & $\begin{array}{l}\text { 을 } \\
\text { 믐 } \\
0 \\
\text { 乙 }\end{array}$ & 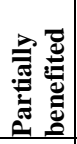 & 吾 \\
\hline There are a few challenges of using AI for Accounting Work & & & & & \\
\hline Lack of Experience in the Initial Stage & & & & & \\
\hline High Investment with Slow Return & & & & & \\
\hline The Quality of Professional Talents Needs to Be Improved & & & & & \\
\hline Accounting Personnel Training Program in Colleges Needs Adjustment & & & & & \\
\hline Data worth and sizes are crucial for its success & & & & & \\
\hline It learns with increasing quantity of data. & & & & & \\
\hline The Governing body's (ICAI) Support for Application of AI in the Accounting Field & & & & & \\
\hline Businesses with Attributed Standing to the Submission of AI Knowledge & & & & & \\
\hline AI can never duplicate the complicated environment of humanoid aptitude & & & & & \\
\hline It will unable to take control over function in the near impending time & & & & & \\
\hline Accountants frequently uses multinational geographical area which may not be cope up with AI algorithms & & & & & \\
\hline
\end{tabular}

Appendix-2: Details of data

\begin{tabular}{|c|c|c|c|c|c|c|c|c|c|}
\hline \multicolumn{10}{|c|}{ Mod Summary } \\
\hline \multirow[b]{2}{*}{ Mo.. } & \multirow[b]{2}{*}{$\mathrm{R}$} & \multirow[b]{2}{*}{$\mathrm{R}^{2}$} & \multirow[b]{2}{*}{ Adjusted $\mathrm{R}^{2}$} & \multirow{2}{*}{$\begin{array}{c}\sigma \text { Error of } \\
\text { the Est. }\end{array}$} & \multicolumn{5}{|c|}{ Change Statistics } \\
\hline & & & & & $\mathrm{R}^{2}$ Change & F-change & df1 & df2 & Sig. F-Ch. \\
\hline 1 & $.477^{\mathrm{a}}$ & 228 & 220 & .78567 & 228 & 30.095 & 1 & 102 & .00 \\
\hline 2 & $.590^{\mathrm{b}}$ & 348 & 335 & .72574 & .120 & 18.540 & 1 & 101 & .000 \\
\hline
\end{tabular}

a. Predictors: (Constant), Pol_chang_6

b. Predictors: (Constant), Pol_chang_6, Pol_chang_3

\begin{tabular}{|c|c|c|c|c|c|c|}
\hline \multicolumn{7}{|c|}{ ANOVA $^{c}$} \\
\hline \multicolumn{2}{|c|}{ Model } & SS & $\mathrm{df}$ & MS & $\mathrm{F}$ & Sig. \\
\hline \multirow[t]{3}{*}{2} & Reg. & 28.342 & 2 & 14.171 & 26.905 & $.000^{\mathrm{b}}$ \\
\hline & Resi.l & 53.197 & 101 & .527 & & \\
\hline & Total & 81.538 & 103 & & & \\
\hline
\end{tabular}

b. Predictors: (Constant), Pol_chang_6, Pol_chang_3

c. Dependent Variable: Pol_chang_1

\begin{tabular}{|c|c|c|c|c|c|c|}
\hline \multicolumn{7}{|c|}{ Coefficients $^{\mathrm{a}}$} \\
\hline & & Unstandardize & oefficients & $\begin{array}{l}\text { Standardized } \\
\text { Coefficients }\end{array}$ & & \\
\hline \multicolumn{2}{|c|}{ Model } & B & Std. Error & Beta & $\mathrm{t}$ & Sig. \\
\hline \multirow[t]{2}{*}{1} & (Constant) & 1.201 & .222 & & 5.399 & .000 \\
\hline & Pol_chang_6 & .515 & .094 & .477 & 5.486 & .000 \\
\hline \multirow[t]{3}{*}{2} & (Constant) & .572 & .252 & & 2.269 & .025 \\
\hline & Pol_chang_6 & .488 & .087 & .452 & 5.606 & .000 \\
\hline & Pol chang 3 & .287 & .067 & .347 & 4.306 & .000 \\
\hline
\end{tabular}

a. Dependent Variable: Pol_chang_1

\begin{tabular}{|c|c|c|c|c|c|c|c|c|c|}
\hline \multirow[b]{2}{*}{ Mo.. } & \multirow[b]{2}{*}{$\mathrm{R}$} & \multirow[b]{2}{*}{$\mathrm{R}^{2}$} & \multirow[b]{2}{*}{ Adjusted $\mathrm{R}^{2}$} & \multirow{2}{*}{$\begin{array}{c}\sigma \text { Error of } \\
\text { the Est. }\end{array}$} & \multicolumn{5}{|c|}{ Change Statistics } \\
\hline & & & & & $\mathrm{R}^{2}$ Change & F-change & df1 & $\mathrm{df2}$ & Sig. F Cl \\
\hline 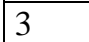 & $.409^{c}$ & .168 & 143 & .92690 & .054 & 6.531 & 1 & 100 & .01 \\
\hline
\end{tabular}

c. Predictors: (Constant), Benefits_3, Benefits_12, Benefits_18

ANOVA $^{\mathrm{d}}$

\begin{tabular}{|l|l|r|r|r|r|r|}
\hline Model & \multicolumn{2}{|c|}{ SS } & \multicolumn{1}{c|}{ df } & MS & \multicolumn{1}{c|}{ F } & Sig. \\
\hline \multirow{3}{*}{3} & Reg. & 17.307 & 3 & 5.769 & 6.715 & $.000^{c}$ \\
\cline { 2 - 8 } & Res. & 85.914 & 100 & .859 & & \\
\cline { 2 - 8 } & Total & 103.221 & 103 & & & \\
\end{tabular}

c. Predictors: (Constant), Benefits_3, Benefits_12, Benefits_18

d. Dep.Var.: Benefits_2 
Measuring Accounting Professionals Perception on use of AI Based Accounting Practices in India

\begin{tabular}{|c|c|c|c|c|c|c|}
\hline \multicolumn{7}{|c|}{ Coeff. } \\
\hline \multirow{2}{*}{\multicolumn{2}{|c|}{ Mod.. }} & \multicolumn{2}{|c|}{ Unst. Coef. } & \multirow{2}{*}{$\begin{array}{c}\text { Stand.. Coeff.. } \\
\text { Beta } \\
\end{array}$} & \multirow[b]{2}{*}{$\mathrm{t}$} & \multirow[b]{2}{*}{ Sig. } \\
\hline & & $\mathrm{B}$ & Std. Error & & & \\
\hline \multirow[t]{4}{*}{3} & (Constant) & 1.232 & .348 & & 3.546 & .001 \\
\hline & Benefits_3 & .286 & .094 & .280 & 3.053 & .003 \\
\hline & Benefits_12 & .190 & .070 & .249 & 2.712 & .008 \\
\hline & Benefits_18 & -.214 & .084 & -.234 & -2.556 & .012 \\
\hline
\end{tabular}

a. Dependent Variable: Benefits_2

\begin{tabular}{|c|c|c|c|c|c|c|c|c|c|}
\hline \multicolumn{10}{|c|}{ Mod Sum. } \\
\hline \multirow[b]{2}{*}{ Mod. } & \multirow[b]{2}{*}{$\mathrm{R}$} & \multirow[b]{2}{*}{$\mathrm{R}^{2}$} & \multirow[b]{2}{*}{ Adj. $\mathrm{R}^{2}$} & \multirow[b]{2}{*}{$\begin{array}{c}\sigma \text { Error of } \\
\text { the Est. }\end{array}$} & \multicolumn{5}{|c|}{ Chang-Statistics } \\
\hline & & & & & $\begin{array}{c}\mathrm{R}^{2} \\
\text { Change }\end{array}$ & F-Change & df1 & df2 & Sig. F Ch. \\
\hline 4 & $.439^{\mathrm{d}}$ & .193 & .160 & 1.05999 & .037 & 4.535 & 1 & 99 & .036 \\
\hline
\end{tabular}

d. Predictors: (Constant), Challang_4, Challang_3, Challang_9, Challang_2

\begin{tabular}{|c|c|c|c|c|c|c|}
\hline \multicolumn{7}{|c|}{ 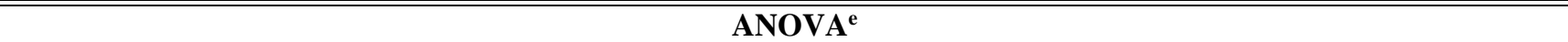 } \\
\hline \multicolumn{2}{|c|}{ Mod. } & SS & $\mathrm{df}$ & MS & $\mathrm{F}$ & Signif. \\
\hline \multirow[t]{3}{*}{4} & Reg. & 26.602 & 4 & 6.651 & 5.919 & .000 \\
\hline & Res. & 111.235 & 99 & 1.124 & & \\
\hline & Total & 137.837 & 103 & & & \\
\hline
\end{tabular}

d. Predictors: (Constant), Challang_4, Challang_3, Challang_9, Challang_2

e. Dependent Variable: Challang_1

\begin{tabular}{|c|c|c|c|c|c|c|}
\hline \multicolumn{7}{|c|}{ Coefficients $^{\mathrm{a}}$} \\
\hline \multirow{2}{*}{\multicolumn{2}{|c|}{ Mod. }} & \multicolumn{2}{|c|}{ Unst. Coeff. } & \multirow{2}{*}{$\begin{array}{c}\text { Stand. Coeff. } \\
\beta\end{array}$} & \multirow[b]{2}{*}{$\mathrm{t}$} & \multirow[b]{2}{*}{ Sig. } \\
\hline & & $\beta$ & ǒ. Error & & & \\
\hline \multirow[t]{5}{*}{4} & (Con.) & 1.027 & .638 & & 1.611 & .110 \\
\hline & Challang_4 & .285 & .106 & .248 & 2.682 & .009 \\
\hline & \begin{tabular}{|l|} 
Challang_3 \\
\end{tabular} & .305 & .107 & .262 & 2.865 & .005 \\
\hline & \begin{tabular}{|l|} 
Challang_9 \\
\end{tabular} & .224 & .098 & .210 & 2.287 & .024 \\
\hline & \begin{tabular}{|l|} 
Challang_2 \\
\end{tabular} & -.225 & .106 & -.193 & -2.129 & .036 \\
\hline
\end{tabular}

\section{AUTHORS PROFILE}

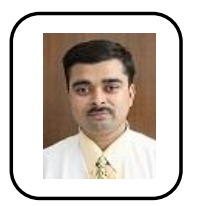

Dr. Vineet Chouhan is PhD in Commerce, MBA-ABST, MBA-FM, UGC NET\& SLET- Commerce and UGC NET in Management. He has 17+ years of experience and is currently working at Assistant Professor at Sir Padampat Singhania University, Udaipur-Rajasthan from last 10 years. He has authored 12 books in the area of Accounting, Auditing and GST including 03 reference books, over 50 research papers published and Presented papers in 60+ conferences. He has also conducted 2 FDP and 10 Seminar's successfully. He is conducting FDP to various organizations like IOV. He is in the review board of national and international journals.

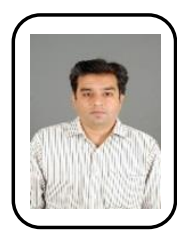

Dr. Pushpkant Shakdwipee is Ph.D, NET is commerce with Accountancy as his Specialization.He is presently working as Associate Professor at Pacific Institute of Management,Pacific University from last 11 Years..He holds 17 Years of experience as various academic positions.He has co authored 5 books on Goods and services Tax. He is also the co author of Accountancy book for class 12, published by Rajasthan Board of Secondary Education.He has also presented papers in more than 50 Seminars and conferences along with paper publications in various journals of high repute.He is in the review board of international Journal.

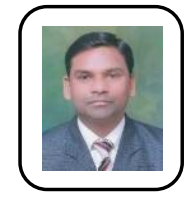

Dr. M.L.Vasita is Associate Professor, Department of Business Administration, University of Rajasthan, Jaipur (Rajasthan,India). He obtained his Ph.D., M.Com., PGDLL degrees from Mohanlal Sukhadia University, Udaipur and also an MBA degree from IGNOU, New Delhi. He has presented papers in various National and International Conferences. He has also conducted workshops and Seminars successfully. He has 17 years' of teaching experience in the areas of Human Resource Management and Marketing Management.

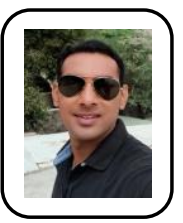

Dr. Poonam Chand is having qualification of $\mathrm{Ph} . \mathrm{D}$. in commerce from University of Rajasthan, Jaipur, $\mathrm{M}$. Com-ABST, UGC-NET, and Rajasthan SET. He has 7+ years of experience of teaching in various colleges of Rajasthan. He is currently working as Assistant Professor and Head Department of Commerce t SMCC government college, Abu Road-Rajasthan since last 2 years. He has 7 paper published in the journal of repute and presented more than 10 research papers in national and international conferences and awarded one best paper presented award too. He has also attended FDP program successfully with A+ Grade. 